\title{
Notice Board
}

The Notice Board seeks to publicise all matters relating to Sartre scholarship, most importantly publications, but also higher degrees (in progress or completed), forthcoming seminars and conferences. We are also pleased to publish conference reports and other Sartre news.

All information should be sent to:

John Gillespie, School of Languages, Literatures and Cultures, University of Ulster, Cromore Road, Coleraine, Co. Londonderry, U.K.; e-mail: J.Gillespie@ulster.ac.uk. His telephone number is 00 442870124636.

\section{Internet Sites}

The U.K. Society for Sartre Studies website: http://www.sartreuk. org, has sections on News, New Publications, Bibliography, On-line Resources, Sartre Links, Conferences and Events, Sartre Studies International, the Sartre Centenary and other archival material. It aspires to being an important research resource and a primary port of call for all Sartre scholars and researchers.

The French Internet site http://www.ges-sartre.fr is the site of the Groupe d'Etudes Sartriennes (GES), based in Paris. It has sections on Etudes Sartriennes, Sartre societies, conferences and other activities, news about Sartre studies, a bibliography of recent books, theses and articles, details of useful Internet links and an information exchange facility. Michel Rybalka also continues to maintain the site http://www.jpsartre.org/.

\section{SARTRE SOCIETIES}

\section{U.K. Sartre Society Annual Conference 2010}

The 17th Annual Conference of the U.K. Sartre Society was held at the Institut Français, 17 Queensberry Place, London SW7 (whose 
support we gratefully acknowledge) on Friday 24 September 2010, organized by Ben O'Donohoe and Angela Kershaw. The following papers were presented:

Keynote Address

Jean-Pierre Boulé (Nottingham Trent University): 'Sartre and Women: The Place of Lena Zonina'.

\section{Sartre in Dialogues}

Alfred Betschart (Independent Scholar): 'Sartre and Adler: Individual Psychology and Existential Psychoanalysis'.

Anu Selvaraj (National University of Singapore): 'Sartre and Levinas: On Subjectivity'.

Iain Stewart (University of Manchester): 'Sartre and Aron: Covert Dialogue from the Cabiers to the Critique'.

\section{Sartre and the Arts}

Noel E. Boulting (Independent Scholar): 'Sartre on Baudelaire: Literary Interpretation Distorted by Philosophy?'

Tim Huntley (University of Sussex): 'Grace Revealed and Erased: Sartre on Tintoretto's Modest Plenitude'.

At the AGM a new committee was voted into place for the next three years: President: Professor John Gillespie (University of Ulster); Secretary: Dr Jonathan Webber (University of Cardiff); Treasurer: Dr Debbie Evans; Committee Members: Dr Bradley Stephens (University of Bristol), Rebecca Pitt (University of Essex).

Groupe Belge d'Etudes Sartriennes: Journées d'Etudes, Université de Liège

Study days on the theme of 'Politiques de la littérature: Bourdieu, Sartre, Foucault', organized by Grégory Cormann (Université de Liège) and Thomas Bolmain (FNRS-Université de Liège) were held on 29 and 30 April 2010 at the University of Liège. The following papers were presented:

Jean-François Louette (Paris IV-Sorbonne): 'Le deuxième sexe dans Les Mains sales.' 
Gianluca Vagnarelli (Université de Liège): 'Démocratie et communication littéraire dans Qu'est-ce que la littérature? de Sartre'.

Jacques Lecarme (Paris III-Sorbonne Nouvelle): 'Sartre et Bourdieu: Refus de l'autobiographie, passage à l'acte autobiographique, présence inévitable de Flaubert'.

Jacques Dubois (Université de Liège): 'Flaubert analyste de Bourdieu'.

François Provenzano (FNRS-Université de Liège): 'L'ellipse du sujet. Bourdieu et Foucault face à la littérature comme discours'.

Thomas Bolmain (FNRS-Université de Liège): 'Une éthique de la littérature: Foucault, de Kant à Lacan'.

Daniel Giovannangeli (Université de Liège): 'Entre littérature et philosophie. Mallarmé et Derrida'.

Julien Pieron (FNRS-Université de Liège): 'De l'hermétisme' à l'émancipation -réflexion sur le Mallarmé de Rancière'.

Philippe Sabot (Lille III): 'L'engagement imaginaire de Jean-Paul Sartre'.

Fabio Caprio Leite de Castro (CAPES-Université de Liège): 'Le public et l'esprit objectif chez Sartre'.

Grégory Cormann (Université de Liège): "Des muets qui veulent parler'. Politique, langue et littérature chez le dernier Sartre'.

\section{North American Sartre Society}

The 18th Biennial Conference of the North American Sartre Society will be hosted by TÉLUQ, Montréal, from 27 to 29 April 2011. The following papers are to be presented:

Peter Jones (Independent scholar): 'Performance Enhancement through Bad Faith: Inauthenticity, Transcendence and High-Risk Sports'.

Claudio Majolino (Université de Lille 3): 'De la dégradation'. Nathanaël Masselot (Université de Lille 3): 'La magie de la néantisation'.

Roland Breeur (Katholieke Universiteit-Husserl Archives Leuven): 'Temps irréel et creatio continua'.

Jonathan Judaken (University of Memphis): 'Christian Responses to Sartre and the Origins of Existentialism'. 
Matthew Lexow (University of Memphis): 'The Humanization of Death: The Role of Need in Sartre's 1964 Rome Lecture'.

William Samson (University of Western Ontario): 'The Bastard Ideology: Sartre on Law'.

Nicolas de Warren (Wellesley College): 'La fascination de l'immanence: la phénoménologie sartrienne du rêve'.

T. Storm Heter (East Stroudsburg University of Pennsylvania): 'Fakers, or Why the Andy Warhol Generation Aborted Authenticity'.

Craig Matarrese (Minnesota State University-Mankato): 'Jazz Is Like a Banana'.

Karine Abadie (Université de Montréal): 'Le cinéma selon Sartre'.

Nao Sawada (Université Rikkyo): 'Sartre et la photographie: autour de la théorie de l'imaginaire'.

Stephanie Adair (Duquesne University): 'How Sartre Explains Psychological Symptoms without Splitting Consciousness'.

Erik Nakjavani (University of Pittsburgh): 'Between Logos and Pathos: The Evolution of Sartrean Psychoanalytic Metatheory'.

Boussad Berrichi (Université de Paris): 'Jean-Paul Sartre et Albert Camus. Deux intellectuels - deux guerres: de la deuxième guerre mondiale à la guerre d'Algérie'.

Maxime Julien (UQÀM): 'Intentionnalité et conscience de soi: la théorie sartrienne de la conscience et sa pertinence actuelle'.

Vanessa Besand (Université de Bourgogne): 'Dialogue de Sartre avec les romanciers américains: l'exemple de L'Enfance d'un chef'.

Claudia Bouliane (Université McGill): 'Martyrs pacifistes dans une foule mystifiée: Jacques Thibault et Philippe Grésigne face à la mobilisation'.

Antoine Krieger (Washington University, St Louis): 'Genet et Sartre: La Question de la Palestine'.

Kavita G. Daby (Université de Maurice): 'Les romans de Sartre et le réel'.

Cameron Clayton (University of Guelph): 'Traversing Time Backwards: The Emanation of Consciousness in Sartre, Nietzsche, and Dennett'. 
Steven W. Quackenbush (University of Maine at Farmington): 'Sartre and Attachment Theory'.

Joshua L. Tepley (University of Notre Dame): 'Sartre on Consciousness and the Ego'.

Matthew C. Eshleman (University of North Carolina, Wilmington): 'The Transcendental Nature of Sartre's Central Argumentative Strategy in Being and Nothingness'.

Stanley Konecky (Hartwick College): 'Naked Shame: Sartre on Shame'.

Danielle M. LaSusa (Southwest Minnesota State University): 'Possession of the Material World in Sartre's Being and Nothingness'.

Solange Guénoun (Université du Connecticut): 'Entre Sartre et Flaubert: les fictions de Jacques Rancière'.

Serge Zenkine (Université des Sciences Humaines (RGGU) Moscou): 'Deux nouveaux mystiques: le sacré selon Bataille et Sartre'.

Mamadou Abdoulaye Ly (Mary Immaculate College-University of Limerick): 'La littérature intime en débat dans Les carnets de la drôle de guerre'.

Rebecca Pitt (University of Essex): 'Two Revolutionaries?'

Damon Boria (Purdue University): 'Sartre on Moral and Political Authority'.

Marie-Andrée Charbonneau (Université de Moncton): 'Les annotations de Sartre dans l'Éthique de Spinoza. Pistes d'interprétation'.

André Duhamel (Université de Sherbrooke): 'Éthique et Situation: Sartre et Dewey'.

Ron Aronson (Wayne State University): 'Sartre as Essayist'.

Devin Zane Shaw (University of Ottawa): 'The Being and Nothingness of Equality: Sartre's Influence on Rancière'.

Ian Coleman (Katholieke Universiteit Leuven): 'From Pathos to Pathology: Jean-Paul Sartre's Imaginative Consciousness and Its Implications for Michel Henry's Pure Immanence'.

Régine Robin (Professeure émérite, Université du Québec à Montréal): 'Illisible Sartre'. 
Christopher R. Wood (University of Guelph): 'Re-apprehending Sartrean Encounters: 'Conflict' and 'Concrete Relations' in Being and Nothingness'.

Insook Webber (University of Washington): 'Pure and Applied Consciousness in Valéry and Sartre'.

Martine Berenpas (Leiden University): 'The Possibility of Authentic Love in the Philosophy of Jean-Paul Sartre'.

Matthew C. Ally (City University of New York-BMCC): 'Sartre and the Dialectic of Nature: A Reappraisal in Light of Recent Science'.

Dennis Skocz (Independent Scholar): 'Sartre, the Market, and the Meltdown: Readings from the Critique of Dialectical Reason, Volume I'.

Austin H. Smidt (University of Dundee): 'Becoming 'L'Homme Imaginaire': Imagining Our Way Out of Circularity in Sartre's CDR'.

Lior Levy (Temple University): 'Memory and Imagination in Sartre's The Imaginary'.

Daniel O'Shiel (Katholieke Universiteit Leuven): 'Magical Being: Sartre's Imaginary as Being-For-Itself'.

Bill Martin (DePaul University): 'Sartre and the legacy of French Marxism: After Althusser and Badiou'.

David Lethbridge (Okanagan College): 'Praxis and the Objective Ideal in Sartre and Ilyenkov'.

Adrian van den Hoven (University of Windsor): 'Sartre's Conception of Theater. Theory and Practice/La conception sartrienne du théâtre. Théorie et pratique'.

John Ireland (University of Illinois at Chicago): 'Censorship and Sartre's Theatrical Project/La censure et le projet théâtral de Sartre'.

Benedict O'Donohoe (University of Sussex): 'Parallel Plays: Camus's Les Justes and Sartre's Les Mains sales/Parallèles entre Les Justes de Camus et Les Mains sales de Sartre'.

Dennis Gilbert (Boston College-University of Massachussets, Boston): 'Simone de Beauvoir on Existentialist Theater/Simone de Beauvoir parle du théâtre existentialiste'. 


\section{Groupe d'Etudes Sartriennes Annual Conference}

The Annual Conference of the Groupe d'Etudes Sartriennes will be held at the Sorbonne on 24 and 25 June 2011. Papers on all aspects of Sartre Studies will be presented.

\section{SARTRE NEWS AND NEWS OF CONFERENCES ON SARTRE}

\section{Sartre's Huis clos}

There were seven performances, in French, of Sartre's Huis clos staged by a cast of professional native French actors from 5 to 10 October 2010 at the Barons Court Theatre, London.

\section{Cambridge French Graduate Conference}

The Cambridge French Graduate Conference, Le Caur dans tous ses états ..., was held at Clare College, Cambridge from 18 to 19 March. Dr Andy Martin (University of Cambridge), gave a keynote address on 'What It Feels Like: According to Sartre and Camus'.

\section{Bristol Lecture}

Bradley Stephens (University of Bristol) delivered a lecture entitled 'Sartre, the Surreptitious Romantic? Reading Existentialism alongside Romanticism', on 22 April 2010 at the University of Bristol.

\section{Reading Sartre on Phenomenology and Existentialism}

The two-day conference organized by Jonathan Webber's AHRC Reading Sartre Project at Cardiff University in conjunction with ITEM, ENS-CNRS, was held in the Salle des Actes at the Ecole Normale Supérieure, 45 rue d'Ulm, Paris on 20 and 21 September 2010. The papers presented were:

Christine Daigle (Brock): 'The Ethics of Authenticity'.

Andreas Elpidorou (Boston): 'Imagination in Non-Representational Painting'.

Matt Eshleman (North Carolina, Washington): 'What Is It Like To Be Free?'

Sebastian Gardner (UCL): 'The Transcendental Dimension of Sartre's Philosophy'. 
Azzedine Haddour (UCL): 'Being Colonized' .

Anthony Hatzimoysis (Athens): 'A Sartrean Critique of Introspection'. Andrew Leak (UCL): 'The Significance of Context in Illustrative Examples'.

Katherine Morris (Oxford): 'The Graceful, the Ungraceful and the Disgraceful'.

Sarah Richmond (UCL): 'The Magical in Sartre's Early Philosophy'.

Tony Stone (London South Bank): 'Knowledge of Other People'.

Jonathan Webber (Cardiff): 'Bad Faith and the Other'.

Ken Williford (Texas at Arlington): 'Pre-Reflective SelfConsciousness and the Autobiographical Ego'.

Dan Zahavi (Copenhagen): 'Shame and the Exposed Self'.

L'Imaginaire de Jean-Paul Sartre, Conference at the University of Lille

A conference took place on Thursday 10 February 2011 at the University of Lille 3: 'Autour de L'Imaginaire de Jean-Paul Sartre: phénoménologie, esthétique, littérature', organized by Philippe Sabot (Lille 3-UMR 8163) and Nathanaël Masselot (Lille 3-UMR 8163). The following papers were presented:

Vincent de Coorebyter (CRISP): 'De Husserl à Sartre: la structure intentionnelle de l'image dans L'Imagination et dans L'Imaginaire'.

Nathanaël Masselot (Lille 3-UMR 8163): 'L'unité imaginaire: le problème de l'unité dans la phénoménologie et l'ontologie sartriennes'.

Philippe Sabot (Lille 3-UMR 8163): 'De L'Imaginaire à L'Idiot de la famille: la tentation de l'irréel'.

Roland Breeur (Katholieke Universiteit Leuven): 'Un peu de temps à l'état pur. Quelques remarques sur le temps imaginaire'.

Bernard Sève Sabot (Lille 3-UMR 8163): 'L'Imaginaire et la musique. Jean-Paul Sartre, Roman Ingarden et Boris de Schloezer'. 


\section{L'Actualité de Jean-Paul Sartre, Conference at the University of Lucerne}

The conference, 'L'actualité de Jean-Paul Sartre: philosophie, littérature, politique', will take place in Lucerne in Switzerland on 17 and 18 March 2011. The following papers are to be presented:

Vincent von Wroblewsky (Berlin): ' ... on n'est point sot tout seul. ... Quelques réflexions avec Sartre sur un sujet d'actualité'.

Ronald E. Santoni (Granville, Ohio): 'The pervasiveness of 'bad faith' in Sartre's philosophy - and the continuing impact of it'.

Ronald Aronson (Detroit): 'Sartre, moralist for the present'.

Michel Sicard (Paris): 'Sartre théoricien d'une nouvelle esthétique'.

Ingrid Galster (Paderborn): 'L'actualité de Sartre, hier et aujourd'hui'.

Annie Cohen-Solal (Paris-New York): 'Sartre, penseur précoce du post-colonial'.

Luc Ferry (Paris): 'Epiméthée, Pic de la Mirandole, Sartre. La définition de l'homme comme néant et la naissance de l'humanisme moderne'.

\section{SARTRE BIBLIOGRAPHY}

\section{5}

\section{Secondary Literature}

Articles

Contat, Michel, 'La genèse sociale des Séquestrés d'Altona de Jean-Paul Sartre', Genesis. Manuscrits, recherche, invention, 2005, 26: 91-99. Grell, Isabelle, 'Ecriture et désécriture d'un trio romanesque', Genesis. Manuscrits, recherche, invention, 2005, 25: 11-30.

Ireland, John, 'Le Keane Sartre: personnage ou concept?', Genesis. Manuscrits, recherche, invention, 2005, 25: 31-46.

Philippe, Gilles, 'Construction du personnage et argumentation philosophique (sur un scenario inédit de Jean-Paul Sartre', Genesis. Manuscrits, recherche, invention, 2005, 25: 47-55.

\section{6}

\section{Secondary Literature}

Articles

Benoît, Denis, 'Politiques de l'autobiographie chez Sartre', Les Temps modernes, 2006, 641: 149-167. 
Louette, Jean-François, 'Eclats autobiographiques dans L'Etre et le néant, Les Temps modernes, 2006, 641: 168-196.

\section{7}

\section{Secondary Literature}

\section{Books}

Carney, John C., Rethinking Sartre: A Political Reading. Lanham, Maryland: University Press of America, 2007, 139.

Law, David R., Sartre's Existentialism and Humanism. London: SCM, 2007, 108.

Palmer, Donald D., Sartre for Beginners. Danbury, Conn: For Beginners, 2007, 160.

Sherman, David, Sartre and Adorno: The Dialectics of Subjectivity. Albany: SUNY Press, 2007, 340.

Wald Lasowski, Aliocha, “L'Enfance d'un chef” de Jean-Paul Sartre', Paris: Gallimard, 2007, 144.

\section{Chapters in Books}

De Coorebyter, Vincent, 'Sartre et l'être du néant' in Dire le néant, ed, J Laurent, Caen: Presses Universitaires de Caen, 2007, 345-364.

\section{Articles}

Anselmini, Julie, 'Les stratégies argumentatives dans L'Idiot de la famille', Recherches et travaux, 2007, 71: 67-78.

Aucagne, Julie, 'Achille-Cléophas Flaubert et les métamorphoses du regard chirurgical' Recherches et travaux, 2007, 71: 125-137.

Bourgault, Jean, 'Réinventer l'art d'écrire': littérature et phénomélologie dans L'Idiot de la famille', Recherches et travaux, 2007, 71: 125-137.

Cormann, Grégory, 'L'indisable' sartrien entre Merleau-Ponty et Lacan: inventer une étrange histoire de L'Idiot de la famille', Recherches et travaux, 2007, 71: 151-176.

Cornille, Jean-Louis, 'Rayons Sartre ou les mots sous Les Mots', Versants, 2007, 53-54: 203-220.

Dennis, Benoît, 'L'écrivain engagé et son lecteur: réflexions sur les limites d'une 'générosité', Modernités, 2007, 26: 211-219.

Depestre, René, 'Sartre dans sa fraternité', Les Temps modernes, 2007, 643644, 192-197.

Fauconnier, Bernard, 'Sartre et Merleau-Ponty: égaux mais pas semblables', Le Magazine littéraire, 2007, 468: 59-61.

Ji, Young-Rae, 'La reconstruction sartrienne de la vie de Flaubert', Recherches et travaux, 2007, 71: 49-64.

Louette, Jean-François, 'Revanches de la bêtise dans L'Idiot de la famille, Recherches et travaux, 2007, 71: 29-48.

Mace, Marielle, “Penser par cas': pratiques de l'exemple et narration dans L'Idiot de la famille', Recherches et travaux, 2007, 71: 79-91. 
Madou, Jean-Paul, 'L'autre, le voyage, le paysage (Sartre, Deleuze, Lévinas', French Studies in Southern Africa, 2007, 37: 127-144.

Mathieu, Anne, 'Jean-Paul Sartre et l'Espagne: du Mur à la préface au Procès de Burgos', Roman, 2007, 20-50, 43: 111-124.

Opelz, Hannes, 'Blanchot et Sartre: entre l'écriture et le monde', Les Temps modernes, 2007, 643-644: 98-246.

Philippe, Gilles, 'Le Protocole prérédactionnel dans L'Idiot de la famille', Recherches et travaux, 2007, 71:139-150.

Pierce, Christine, 'Anti-homosexual and Gay: Rereading Sartre, Hypatia, 2007, 22,1,

Ponte, José Antonio, 'Sartre à La Havane', La Nouvelle Revue Française, 2007, 581: 42-56.

Richmond, Sarah, 'Sartre and Bergson: A Disagreement about Nothingness', International Journal of Philosophical Studies, 2007, 15, 1: 77-95.

Sawada, Nao, 'Biographe malgré lui: L'Idiot de la famille dans le miroir des Mots', Recherches et travaux, 2007, 71: 65-77.

Simont, Juliette, " Il se taisaient et l'homme naissait de leur silence'. A propos de la torture dans l'oeuvre de Sartre', Les Temps modernes, 2007, 643-644: 174-191.

Wang, Stephen, 'The Ambiguity of the Self and the Construction of Human Identity in the Early Sartre', American Catholic Philosophical Quarterly, 2007, 81,1: 73-88.

Williams, Timothy J., 'Sartre, Marcel and The Flies: Restless Orestes in Search of a Café', Midwest Quarterly, 2007, 48.3: 76-405.

\section{8}

\section{Secondary Literature}

\section{Books}

Bernasconi, Robert, How to Read Sartre. New York; WW Norton, 2008, 123. Morris, Katherine J., Sartre. Oxford: Blackwell Publishers, 2008, 184.

Santa, Angels, ed., De Nizan à Sartre: philosophie et narration. Lleida: Pagès, $2008,444$.

\section{Chapters in Books}

Arthur, Paige, 'The Persistence of Colonialism: Sartre, the Left and Identity in Postcolonial France' in Race after Sartre: Antiracism, Africana Existentialism, Postcolonialism, ed. Jonathan Judaken. Albany: State University of New York, 2008.

Bernasconi, Robert, 'Sartre and Levinas: Philosophers against Racism and Antisemitism' in Race after Sartre: Antiracism, Africana Existentialism, Postcolonialism, ed. Jonathan Judaken. Albany: State University of New York, 2008.

Butler, Judith, 'Violence and Non-Violence: Sartre on Fanon' in Race after Sartre: Antiracism, Africana Existentialism, Postcolonialism, ed. Jonathan Judaken. Albany: State University of New York Press, 2008. 
Ciccariello-Maher, George, 'European Intellectuals and Colonial Difference: Césaire and Fanon beyond Sartre and Foucault' in Race after Sartre: Antiracism, Africana Existentialism, Postcolonialism, ed. Jonathan Judaken. Albany: State University of New York Press, 2008.

Delacampagne, Christian, 'Race: From Philosophy to History' in Race after Sartre: Antiracism, Africana Existentialism, Postcolonialism, ed. Jonathan Judaken. Albany: State University of New York Press, 2008.

Gordon, Lewis R., 'Sartre and Black Existentialism' in Race after Sartre: Antiracism, Africana Existentialism, Postcolonialism, ed. Jonathan Judaken. Albany: State University of New York Press, 2008.

Judaken, Jonathan, 'Sartre on Racism: From Existential Phenomenology to Globalization and the 'new New Racism" in Race after Sartre: Antiracism, Africana Existentialism, Postcolonialism, ed. Jonathan Judaken. Albany: State University of New York Press, 2008.

Martinot, Steve, 'Skin for Sale: Race and The Respectful Prostitute' in Race after Sartre: Antiracism, Africana Existentialism, Postcolonialism, ed. Jonathan Judaken. Albany: State University of New York Press, 2008.

More, Mabogo P., 'Sartre and South African Apartheid' in Race after Sartre: Antiracism, Africana Existentialism, Postcolonialism, ed. Jonathan Judaken. Albany: State University of New York Press, 2008.

Watts, Richard H., Difference/Indifference: Sartre, Glissant, and the Race of Francophone Literature' in Race after Sartre: Antiracism, Africana Existentialism, Postcolonialism, ed. Jonathan Judaken. Albany: State University of New York Press, 2008.

\section{Articles}

de Coorebyter, Vincent, 'Le Manuscrit-Liberté-Egalité', Etudes Sartriennes, 2008, 12: 155-163.

Louette, Jean-François, 'La Chambre' de Sartre ou la folie de Voltaire', Poétique, 2008, 153: 41-61.

\section{9}

\section{Secondary Literature}

\section{Books}

Crittenden, Paul, Sartre in Search of an Ethics. Newcastle upon Tyne: Cambridge Scholars Press, 2009, 181.

Morris, Katherine J., ed., Sartre on the Body. London: Palgrave MacMillan, 2009, 272.

Tamassia, Paolo, Sartre e il Novocento. Trento: Università degli Studi di Trento, 2009, 161.

\section{Chapters in Books}

Behnke, E.A., 'The Socially Shaped Body and the Critique of Corporeal Experience', in Sartre on the Body, ed. Katherine J. Morris. London: Palgrave MacMillan, 2009. 
Crossley, N., 'The Body and Society: Sartre and the Sociologists', in Sartre on the Body, ed. Katherine J. Morris. London: Palgrave MacMillan, 2009.

Cassam, Q., Representing Bodies', in Sartre on the Body, ed. Katherine J. Morris. London: Palgrave MacMillan, 2009.

Catalano, Joseph, 'The Body and the Book: Reading Being and Nothingness', in Sartre on the Body, ed. Katherine J. Morris. London: Palgrave MacMillan, 2009.

Gordon, L.R., 'Sartre and Fanon on Embodied Bad Faith', in Sartre on the Body, ed. Katherine J. Morris. London: Palgrave MacMillan, 2009.

Howells, C., 'Sartre and Death: Forgetting the Mortal Body in Being and Nothingness', in Sartre on the Body, ed. Katherine J. Morris. London: Palgrave MacMillan, 2009.

Langer, M., 'Sartre in the Company of Merleau-Ponty, Foucault and Duden', in Sartre on the Body, ed. Katherine J. Morris. London: Palgrave MacMillan, 2009.

Mace, Marielle, 'Etre ses propres possibles': lecture et imagination morale chez Sartre', in Pensée morale et genres littéraires, eds. Jean-Charles Darmon and Philippe Desan. Paris: Presses Universitaires de France, 2009.

Mace, Marielle, 'Un type qui relit': Sartre et l'imagination des Anciens', in Fictions d'histoire littéraire, ed. Jean-Louis Jeannelle. Rennes: Presses Universitaires de Rennes, 2009, 113-126.

Mirvish, Adrian, 'Sartre and the Lived Body: Negation, Non-Positional SelfAwareness, and Hodological Space', in Sartre on the Body, ed. Katherine J. Morris. London: Palgrave MacMillan, 2009.

Moran, Dermot, 'Husserl, Sartre and Merleau-Ponty on Embodiment, Touch and the 'Double Sensation", in Sartre on the Body, ed. Katherine J. Morris. London: Palgrave MacMillan, 2009.

Morris, K.J., 'Introduction: Sartre on the Body', in Sartre on the Body, ed. Katherine J. Morris. London: Palgrave MacMillan, 2009.

Morris, K.J., 'The Phenomenology of Clumsiness', in Sartre on the Body, ed. Katherine J. Morris. London: Palgrave MacMillan, 2009.

Morris, P.S., 'Some Patterns of Identification and Otherness', in Sartre on the Body, ed. Katherine J. Morris. London: Palgrave MacMillan, 2009.

Mui, C., 'Sartre and Marcel on Embodiment: Reevaluating Traditional and Gyrocentric Feminisms', in Sartre on the Body, ed. Katherine J. Morris. London: Palgrave MacMillan, 2009.

Peckitt, M.G., 'Resisting Sartrean Pain: Henry, Sartre and Biranism', in Sartre on the Body, ed. Katherine J. Morris. London: Palgrave MacMillan, 2009.

Solomon, R.C., 'Sexual Paradigms', in Sartre on the Body, ed. Katherine J. Morris. London: Palgrave MacMillan, 2009.

\section{Articles}

Anglard, Véronique, 'Pertinence et impertinence de Sartre critique, Mauriac et quelques autres', Nouveaux Cahiers François Mauriac, 2009, 17:

$107-120$. 
Ireland, John, “Ouragon sur le sucre': Sartre, Castro et la révolution cubaine', Les Temps modernes, 2009, 656: 9-37.

Louette, Jean-François, 'L'Enfance d'un chef': la fleur et le coin d'acier', Revue d'Histoire littéraire de la France, 2009, 109.2: 365-384.

Servoise, Sylvie, 'L'Histoire nous saisit': Le Sursis de Jean-Paul Sartre et Le Sentier des nids d'araignée d'Italo Calvino', Roman, 2009, 20-50, 48: $127-138$.

Stralen, Hans von, 'Des mots et des armes': Sartre et la question (post) coloniale à l'époque de l'existentialisme', Orbis Litterarum, 2009, 64.4: 283-299.

\section{0}

\section{Secondary Literature}

\section{Books}

Daigle, Christine, Jean-Paul Sartre. London: Routledge Critical Thinkers Series, 2010, 163.

Catalano, Joseph, Reading Sartre. Cambridge: Cambridge University Press, $2010,240$.

Deguy, Jacques, Sartre: une écriture critique. Villeneuve d'Ascq: Presses Universitaires du Septentrion, 2010, 244.

Mirvish, Adrian and Adrian van den Hoven, eds., New Perspectives on Sartre. Newcastle-upon-Tyne: Cambridge Scholars Press, $2010,450$.

Rius, Mercé, Quatre Essais sur Sartre. Paris: L'Harmattan, 2010, 302.

Webber, Jonathan, Reading Sartre: On Phenomenology and Existentialism. London: Routledge, 2010, 240.

\section{Chapters in Books}

Adams, Sarah LaChance, 'Becoming with Child: Pregnancy as a Provocation to Authenticity', in New Perspectives on Sartre, eds. Adrian Mirvish and Adrian van den Hoven. Newcastle-upon-Tyne: Cambridge Scholars Press, 2010, 25-36.

Anderson, Kenneth L., 'The Future in the Child', in New Perspectives on Sartre, eds. Adrian Mirvish and Adrian van den Hoven. Newcastle-uponTyne: Cambridge Scholars Press, 2010, 12-24.

Anderson, Thomas C., 'Atheistic and Christian Existentialism: A Comparison of Sartre and Marcel', in New Perspectives on Sartre, eds. Adrian Mirvish and Adrian van den Hoven. Newcastle-upon-Tyne: Cambridge Scholars Press, 2010, 44-63.

Aronson, Ronald., 'Sartre after Marxism', in New Perspectives on Sartre, eds. Adrian Mirvish and Adrian van den Hoven. Newcastle-upon-Tyne: Cambridge Scholars Press, 2010, 270-285.

Astier-Verson, Sophie, 'Sartre and Painting', in New Perspectives on Sartre, eds. Adrian Mirvish and Adrian van den Hoven. Newcastle-upon-Tyne: Cambridge Scholars Press, 2010, 214-229. 
Baslev, Anandita N., 'Self-Awareness in Vijnanavada Buddhism and Sartre's Existentialism', in New Perspectives on Sartre, eds. Adrian Mirvish and Adrian van den Hoven. Newcastle-upon-Tyne: Cambridge Scholars Press, 2010, 104-112.

Baugh, Bruce, 'Sartre, Fondane, and Kierkegaard: In Search of the Roots of French Existentialism', in New Perspectives on Sartre, eds. Adrian Mirvish and Adrian van den Hoven. Newcastle-upon-Tyne: Cambridge Scholars Press, 2010, 296-314.

Boulé, Jean-Pierre, 'Sartre and Women: The Place of Lena Zonina', in New Perspectives on Sartre, eds. Adrian Mirvish and Adrian van den Hoven. Newcastle-upon-Tyne: Cambridge Scholars Press, 2010, 191-212.

Bragança, Manual, 'Rethinking German Identity after the Nazi Experience: French Memories of Germans in Sartre's trilogy The Roads to Freedom', in New Perspectives on Sartre, eds. Adrian Mirvish and Adrian van den Hoven. Newcastle-upon-Tyne: Cambridge Scholars Press, 2010, 384402.

Brinker, Menachem, 'Oppression and Violence in Sartre's Thought', in New Perspectives on Sartre, eds. Adrian Mirvish and Adrian van den Hoven. Newcastle-upon-Tyne: Cambridge Scholars Press, 2010, 286-294.

Brydon, James, 'World War Two Reconsidered: From Men Without Shadows to The Condemned of Altona', in New Perspectives on Sartre, eds. Adrian Mirvish and Adrian van den Hoven. Newcastle-upon-Tyne: Cambridge Scholars Press, 2010, 368-383.

Busch, Thomas W., 'Sartre and Merleau-Ponty on Structuralism, Language and Communicative Life', in New Perspectives on Sartre, eds. Adrian Mirvish and Adrian van den Hoven. Newcastle-upon-Tyne: Cambridge Scholars Press, 2010, 315-329.

Cannon, Betty, 'Nothingness at the Heart of Being: Existential Psychoanalysis and Gestalt Therapy', in New Perspectives on Sartre, eds. Adrian Mirvish and Adrian van den Hoven. Newcastle-upon-Tyne: Cambridge Scholars Press, 2010, 412-427.

Daigle, Christine, 'The Ethics of Authenticity', in Reading Sartre: On Phenomenology and Existentialism, ed. Jonathan Webber. London: Routledge, 2010.

Detmer, David, 'Phenomenology and Freedom', in New Perspectives on Sartre, eds. Adrian Mirvish and Adrian van den Hoven. Newcastle-uponTyne: Cambridge Scholars Press, 2010, 114-123.

Elpidourou, Andreas, 'Imagination in Non-Representational Painting', in Reading Sartre: On Phenomenology and Existentialism, ed. Jonathan Webber. London: Routledge, 2010.

Eshlemann, Matthew, 'Sartre on Limited and Conditioned Freedom', in New Perspectives on Sartre, eds. Adrian Mirvish and Adrian van den Hoven. Newcastle-upon-Tyne: Cambridge Scholars Press, 2010, 124-141. Eshlemann, Matthew, 'What Is It Like To Be Free?' Painting', in Reading Sartre: On Phenomenology and Existentialism, ed. Jonathan Webber. London: Routledge, 2010. 
Gardner, Sebastian, 'The Transcendental Dimension of Sartre's Philosophy', in Reading Sartre: On Phenomenology and Existentialism, ed. Jonathan Webber. London: Routledge, 2010.

Gilbert, Dennis A., 'Contemporary Perspectives on Sartre's Theater', in New Perspectives on Sartre, eds. Adrian Mirvish and Adrian van den Hoven. Newcastle-upon-Tyne: Cambridge Scholars Press, 2010, 246-250.

Haddour, Assedine. 'Being Colonized', in Reading Sartre: On Phenomenology and Existentialism, ed. Jonathan Webber. London: Routledge, 2010.

Hatzimoysis, Anthony, 'A Sartrean Critique of Ontrospection', in Reading Sartre: On Phenomenology and Existentialism, ed. Jonathan Webber. London: Routledge, 2010.

Hendley, Steven, 'Realism and Contingency: Elaborating a Viable Sartrean Response to Rorty's Anti-Realism ', in New Perspectives on Sartre, eds. Adrian Mirvish and Adrian van den Hoven. Newcastle-upon-Tyne: Cambridge Scholars Press, 2010, 161-176.

Hopkins, Robert, 'Imagination and Affective Response', in Reading Sartre: On Phenomenology and Existentialism, ed. Jonathan Webber. London: Routledge, 2010.

Kaufmann, Dorothy, 'Reflections on the Yellow Star: Jean-Paul Sartre, Edith Thomas, and Jean Paulhan', in New Perspectives on Sartre, eds. Adrian Mirvish and Adrian van den Hoven. Newcastle-upon-Tyne: Cambridge Scholars Press, 2010, 95-103.

Leak, Andrew, 'The Significance of Context in Illustrative Examples', in Reading Sartre: On Phenomenology and Existentialism, ed. Jonathan Webber. London: Routledge, 2010.

McBride, William L., 'Sartre and the Meaning of History', in New Perspectives on Sartre, eds. Adrian Mirvish and Adrian van den Hoven. Newcastle-upon-Tyne: Cambridge Scholars Press, 2010, 403-410.

Mirvish, Adrian, 'Sartre, Fraternity, and Jewish Messianism: At the Crossroads of Ontology and Metaphysics', in New Perspectives on Sartre, eds. Adrian Mirvish and Adrian van den Hoven, Newcastle-upon-Tyne: Cambridge Scholars Press, 2010, 77-94.

Morris, Katherine, 'Sartre on Consciousness: Remembering the Gestalt Psychology Context', in New Perspectives on Sartre, eds. Adrian Mirvish and Adrian van den Hoven. Newcastle-upon-Tyne: Cambridge Scholars Press, 2010, 142-160.

Morris, Katherine, 'The Graceful, The Ungraceful and the Disgraceful', in Reading Sartre: On Phenomenology and Existentialism, ed. Jonathan Webber. London: Routledge, 2010.

Murray, Elizabeth A., 'Sartre and Lonergan on Consciousness', in New Perspectives on Sartre, eds. Adrian Mirvish and Adrian van den Hoven. Newcastle-upon-Tyne: Cambridge Scholars Press, 2010, 64-75.

O'Donohoe, Benedict, 'Living with Mother: Sartre and the Problem of Maternity', in New Perspectives on Sartre, eds. Adrian Mirvish and Adrian 
van den Hoven. Newcastle-upon-Tyne: Cambridge Scholars Press, 2010, 178-190.

Opelz, Hannes, 'Writing and the World (Sartre, Blanchot)', in New Perspectives on Sartre, eds. Adrian Mirvish and Adrian van den Hoven. Newcastle-upon-Tyne: Cambridge Scholars Press, 2010, 330-366.

Parant, Noémie, 'Sartre: Bodily Experience as a Guiding Thread to the Relationship between Phenomenology and Literature', in New Perspectives on Sartre, eds. Adrian Mirvish and Adrian van den Hoven. Newcastle-upon-Tyne: Cambridge Scholars Press, 2010, 230-245.

Richmond, Sarah, 'Magic in Sartre's Early Philosophy', in Reading Sartre: On Phenomenology and Existentialism, ed. Jonathan Webber. London: Routledge, 2010.

Thomas, Alan, 'Alienation, Objectification, and the Primacy of Virtue', in Reading Sartre: On Phenomenology and Existentialism, ed. Jonathan Webber. London: Routledge, 2010.

Van den Hoven, Adrian, 'Bariona: Sartre's First Play Features a Jewish Village Chief who Saves the Christ-Child at his own Peril', in New Perspectives on Sartre, eds. Adrian Mirvish and Adrian van den Hoven. Newcastle-upon-Tyne: Cambridge Scholars Press, 2010, 251-259. Webber, Jonathan, 'Bad Faith and the Other', in Reading Sartre: On Phenomenology and Existentialism, ed. Jonathan Webber. London: Routledge, 2010.

Williford, Kenneth, 'Pre-Reflective Self-Consciousness and the Autobiographical Ego', in Reading Sartre: On Phenomenology and Existentialism, ed. Jonathan Webber. London: Routledge, 2010.

Wittman, Heiner. 'Art is an Appeal to Freedom', in New Perspectives on Sartre, eds. Adrian Mirvish and Adrian van den Hoven. Newcastle-uponTyne: Cambridge Scholars Press, 2010, 260-268.

Zahavi, Dan, 'Shame and the Exposed Self', in Reading Sartre: On Phenomenology and Existentialism, ed. Jonathan Webber. London: Routledge, 2010.

\section{Articles}

Kakkori, Leena and Rauno Huttunen, 'The Sartre-Heidegger Controversy on Humanism and the Concept of Man in Education', Educational Philosophy and Theory, 9 November 2010: 1-14 early online viewing.

Ally, Matthew C., 'Sartre's Integrative Method: Description, Dialectics and Praxis' Sartre Studies International, 2010, 16.2: 48-74.

Aronson, Ronald, 'Celebrating the Critique's Fiftieth Anniversary, Sartre Studies International, 2010, 16.2 special issue: 1-16.

Aronson, Ronald, 'Living Without God: Reply to Comments', Sartre Studies International, 2010, 16.2: 107-113.

Bernasconi, Robert, 'Fanon's The Wretched of the Earth as the Fulfilment of Sartre's Critique of Dialectical Reason', Sartre Studies International, 2010, 16.2: 36-47. 
Boulé, Jean-Pierre, “Jouer à Sartre-Beauvoir': une chimère bisexuelle' [à propos d'Un amour de soi de Serge Doubrovsky], Dalhousie French Studies, Summer 2010, Numéro spécial: Serge Doubrovsky sous la direction d'Isabelle Grell, 91: 97-106.

Drake, David, 'The 'Anti-Existentialist Offensive': The French Communist Party against Sartre (1944-1948)', Sartre Studies International, 2010, 16.1: 69-94.

Eshleman, Matthew C., 'An Atypical Response to Living Without God', Sartre Studies International, 2010, 16.2: 94-106.

Flajoliet, Alain, 'Sartre's Phenomenological Anthropology between

Psychoanalysis and 'Daseinsanalysis", Sartre Studies International, 2010, 16.1: 40-59.

Flynn, Thomas R., 'Sartre, Foucault and the Critique of (Dialectical)

Reason', Sartre Studies International, 2010, 16.2: 17-35.

Hanscomb, Stuart, 'Existentialism and Art-Horror', Sartre Studies International, 2010, 16.1: 1-23.

Hutchens, Benjamin, Organized Rifts in the Social Fabric: Sartre on the Phenomenon and Praxis of Boxing, Sartre Studies International, 2010, 16.1: 24-39.

Käll, Lisa Folkmarson, 'Fashioned in Nakedness, Sculptured, and Caused to Be Born: Bodies in Light of the Sartrean Gaze', Continental Philosophical Review, 2010, 43: 61-81.

Kerr, Carolyn Michaels, 'Stomaching the Truth: Getting to the Roots of Nausea in the Work of Jean-Paul Sartre and Flannery O'Connor', Christianity and Literature, 2010, 60.1: 67-96.

Santoni, Ronald E., 'The Memphis Session on Living Without God: Including Sartre and Atheism', Sartre Studies International, 2010, 16.2: 85-93.

Van den Hoven, Adrian, 'Sartre and Atheism: An Introduction to the Round-Table Discussion of Ronald Aronson's Living Without God, Sartre Studies International, 2010, 16.2: 75-84.

Vasey, Craig, 'The Day after Existentialism Is A Humanism, and The Last Chance', Sartre Studies International, 2010, 16.1: 60-68. 